\title{
PENDIDIKAN LINGKUNGAN HIDUP DALAM PERSPEKTIF ISLAM
}

\author{
Oleh: \\ Muhaimin ${ }^{1}$ \\ Email: muhaimin_mafandi@yahoo.co.id
}

\begin{abstract}
Preparing young poeple to be able to solve various environmental problems urgently to be done in order to improve and establish better environmental morality. Islam can be the basic and the main of how to build the character of students towards the environment through environmental education that is integrated with Islamic values. Islam forbids explicitly and harshly for humans to do damage on earth as a source of natural disasters as well as encouraging humans to have good character towards nature. Allah made human as caliph on earth, but in utilizing nature must maintain the balance and preservation of the environment, people who damage the environment are hypocrites and very disliked by Allah. Acording to God that peopole who damage the environment is the very transgressors. Element of Islamic values on the environment can be used as material and the main foundation in environmental education in schools.
\end{abstract}

Keywords: education, environment, perspective, Islam

\section{Pendahuluan}

Pendidikan lingkungan hidup berkaitan sangat erat dengan pembentukan pengetahuan dan pemahaman siswa tentang lingkungan hidup yang diikuti dengan perkembangan nilai serta diaplikasikan dalam keterampilan dan partisipasi ekologis dalam kehidupan sehari-hari. Kompetensi ekologis mengisyaratkan apa dan bagaimana individu memahami dan berperilaku terhadap lingkungan hidup yang pada akhirnya membuat individu melek lingkungan (environmental literacy). Melek lingkungan saat ini menjadi salah satu perhatian khusus dalam pengembangan karakter pendidikan di Indonesia. ${ }^{2}$

\footnotetext{
${ }^{1}$ Pendidik di SDN Aengtaber 1 Tanjungbumi Bangkalan Madura

${ }^{2}$ Muhaimin. 2015. Membangun Kecerdasan Ekologis: Model Pendidikan Untuk Peningkatan Kompetensi Ekologis. Bandung: Alfabeta. Hlm 79. 
Nilai-nilai yang dikembangkan dalam pendidikan lingkungan hidup harus sejalan dengan nilai-nilai yang didasarkan pada agama sebagai sumber nilai dalam kehidupan manusia. Dalam konteks faktual, pandangan agama tentang lingkungan hidup tidak banyak diketahui oleh peserta didik. Perilaku terhadap lingkungan juga tidak dilandaskan pada moral agama sebagai penopangnya. Sebagian besar menganggap bahwa agama kurang berhubungan dengan kepedulian terhadap lingkungan, ataupun agama tidak mengatur secara khusus bagaimana manusia berhubungan dengan lingkungannya.

Selanjutnya yang terjadi adalah melepaskan agama dalam pembentukan karakter kepedulian terhadap lingkungan. Kondisi faktual di lapangan menunjukkan pendidik, terutama di tingkat sekolah dasar kurang mengintegrasikan nilai-nilai agama atau pandangan agama terhadap lingkungan dan kepedulian terhadap lingkungan itu sendiri. Padahal, Islam banyak mengajarkan tentang pendidikan lingkungan hidup, bagaimana manusia menjadi khalifah di muka bumi dan berinteraksi secara positif dengan lingkungan alamnya.

Dalam membentuk dan mengembangkan karakter cinta lingkungan perlu diintegrasikan bagaimana pandangan agama secara utuh terhadap lingkungan hidup. Dengan demikian, karakter mencintai lingkungan semakin tumbuh kuat dalam diri peserta didik. Selain itu, peserta didik dapat memahami secara utuh, nilai-nilai ajaran agama yang luar biasa. Hal ini dapat dijadikan pedoman dan penuntun perilaku peserta didik. Internalisasi nilai-nilai dan perilaku yang ditopang oleh nilai agama dapat membentuk nilai secara lebih kuat dalam diri manusia.

Menyiapkan generasi muda untuk mampu menyelesaikan berbagai persoalan lingkungan hidup mendesak untuk dilakukan dalam rangka memperbaiki dan membentuk moralitas lingkungan yang lebih baik. Dalam konteks pendidikan di Indonesia, kemerosotan nilai-nilai moral telah menjadi semacam lampu merah yang mendesak semua pihak, lembaga pendidikan, orangtua, negara, dan lembaga kemasyarakatan yang lain untuk segera memandang pentingnya sebuah sinergi bagi pengembangan pendidikan yang membentuk karakter ekologis pada 
siswa. Banyak bukti menunjukkan bahwa pelaksanaan ecopedagogy di sekolah belum mampu menciptakan kondisi seperti yang diharapkan. Saat ini pihak yang berkompeten dalam jajaran pendidikan merekonstruksi pengembangan ecopedagogy sehingga membentuk karakter ekologis siswa baik di sekolah maupun dalam masyarakat. ${ }^{3}$

\section{Pandangan Islam Tentang Pendidikan Lingkungan Hidup}

Pendidikan lingkungan hidup merupakan salah satu muatan utama dalam pendidikan karakter di Indonesia. Hal ini tercermin dengan terintegrasinya muatan lingkungan hidup dalam pendidikan formal di Indonesia, mulai dari Pendidikan Anak Usia Dini sampai Pendidikan Tinggi. Pendidikan lingkungan hidup dalam sekolah formal di Indonesia diintegrasikan dalam berbagai mata pelajaran di sekolah menengah dan dengan berbagai tema dalam pendidikan dasar. Begitu pentingnya pendidikan lingkungan hidup, dijadikan elemen utama dalam pendidikan karakter di Indonesia.

Esensi ini berangkat dari pemahaman bahwa manusia dan lingkungan menjadi bagian integral dalam kehidupan. Perilaku manusia terhadap lingkungan sangat berpengaruh bagaimana keberlangsungan dan keberlanjutan lingkungan di masa yang akan datang. Selain itu, pendidikan lingkungan hidup juga menentukan dimensi atau bidang kehidupan manusia lainnya yang sangat tergantung terhadap lingkungan, baik fisik maupun sosialnya.

Kompetensi ekologis merupakan kompetensi yang berkaitan dengan aspek-aspek yang berhubungan dengan ekologi dalam konteks pendidikan yang harus dikuasai oleh siswa dalam pembelajaran. Menurut Hines dkk ${ }^{4}$ (2004:2), dalam bukunya "Global Issues and Environment Education", menekankan terbentuknya pengetahuan tentang isu-isu lingkungan yang diaplikasikan secara nyata untuk bertindak mengatasi permasalahan

\footnotetext{
${ }^{3}$ Muhaimin. 2015. Membangun Kecerdasan Ekologis: Model Pendidikan Untuk Peningkatan Kompetensi Ekologis. Bandung: Alfabeta. Hlm 72.

${ }^{4}$ Hines, et.al. (2004). Global Issues and Environment Education. (http//www. eriese.org/erie/digest/digest-05/ html) (12 Oktober 2019). Hlm 2. 
lingkungan hidup yang terjadi. Hines mengidentifikasi empat elemen pokok yang harus ada dalam kompetensi dalam pendidikan lingkungan hidup, yaitu: (1) pengetahuan tentang isu-isu lingkungan; (2) pengetahuan tentang strategi tindakan yang khusus untuk diterapkan pada isu-isu lingkungan; (3) kemampuan untuk bertindak terhadap isu-isu lingkungan; dan (4) memiliki kualitas dalam menyikapi serta sikap personalitas yang baik.

Kompetensi ekologis dalam pandangan Palmer \& Neal ${ }^{5}$ menekankan pada konsep adanya kepekaan dan kepedulian siswa untuk memecahkan permasalahan lingkungan hidup dalam kehidupan sehari-hari sampai pada terbentuknya cara pandang dan etika ideal terhadap lingkungan hidup. Kompetensi ekologis dalam dunia pendidikan yaitu dengan mengembangkan kepekaan, kesadaran, pemahaman, pemikiran kritis dan memecahkan masalah keterampilan yang berhubungan dengan permasalahan lingkungan hidup serta pembentukan etika lingkungan. Dalam konteks ini Palmer \& Neil menekankan pentingnya pemikiran kritis yang berpengaruh ada kepekaan dan kepedulian lingkungan hidup.

Agama sebagai sumber norma manusia, mempunyai komitmen dan tanggungjawab menuntun umatnya dalam mempunyai etika terhadap lingkungan hidup. Agama sebagai sumber nilai dapat merubah alam menjadi suatu sumber kehidupan yang positif (manfaat) maupun negatif (madharat). Pendekatan pendidikan lingkungan hidup dengan menggunakan Islam sebagai sistem nilai dan norma untuk memecahkan masalah kehidupan seluruh makhluk di bumi ini sebagai ungkapan rasa tanggung jawab. Lingkungan hidup merupakan satu kesatuan sistem dan memiliki hubungan yang sanagat banyak dengan penghuni, banyak interaksi dan korelasinya. Lingkungan hidup dalam pandangan Islam

\footnotetext{
${ }^{5}$ Palmer, J. A \& Phlip, N (1994). The Handbook of Environmental Education.
} London: Routledge. Hlm $22-23$. 
tidak terlepas dari proses penciptaan Allah yang tidak secara kebetulan. Kejadian alam semesta yang sistematik mengarahkan manusia agar mampu menghayati wujud, keesaan dan kebesaran Allah. Mengingat karena semua kerusakan atau pencemaran lingkungan disebabkan karena ulah manusia, maka amar ma'ruf nahi mungkar adalah cara terbaik untuk menanggulangi hal tersebut dengan tinjauan secara teologis dan fenomenologis.

Perilaku yang dilandasi dengan agama akan melahirkan moral lingkungan. Moral lingkungan hidup membahas tindakan manusia yang berhubungan dengan tempat tinggalnya dan makhluk-makhluk nonmanusia. Moral lingkungan hidup bukanlah cabang moral, seperti moralmedis dan moral bisnis, tetapi perluasan bidang moral. 6 Moral lingkungan hidup memberikan pertimbangan-pertimbangan filosofis dan biologis mengenai hubungan manusia dengan tempat tinggalnya dan makhluk ciptaan lainnya. 7 Pertimbangan-pertimbangan filosofis yang didasarkan atas agama berarti pertimbangan-pertimbangan yang mendasar, yang sesuai dengan hakikat manusia. Misalnya: manusia adalah makhluk berakal budi, maka ia harus menggunakan akal budinya apabila ingin memutuskan apa yang akan dilakukannya.

Islam sangat memperhatikan dan menjunjung akhlak manusia terhadap alam, yang juga menjadi sumber bencana alam dalam berbagai bentuk. Perilaku manusia berinteraksi dengan alam diatur oleh al-Qur'an secara lengkap. Munculnya fikih lingkungan merupakan respon dari berbagai persoalan umat terutama munculnya permasalahan lingkungan hidup manusia yang sangat kompleks, termasuk di dalamnya tentang bencana alam. ${ }^{8}$

Hlm 37

${ }^{6}$ Chang, William. (2001). Moral Lingkungan Hidup Yogyakarta: Penerbit Kanisius. Hlm 34

${ }^{7}$ Chang, William. (2001). Moral Lingkungan Hidup Yogyakarta: Penerbit Kanisius.

${ }^{8}$ Muhaimin. 2015. Membangun Kecerdasan Ekologis: Model Pendidikan Untuk Peningkatan Kompetensi Ekologis. Bandung: Alfabeta. Hlm 14. 
Elemen nilai Islam terhadap lingkungan dapat dijadikan materi dan landasan utama dalam pendidikan lingkungan hidup di sekolah sebagai berikut.

1) Islam melarang secara tegas dan keras kepada manusia untuk berbuat kerusakan di muka bumi sebagai sumber dari bencana alam

Allah sangat keras melarang manusia membuat kerusakan di muka bumi. Hukuman Allah sangat tegas bagi orang-orang yang merusak lingkungan, sebagaimana firman Allah dalam surat Al Maidah ayat 33:

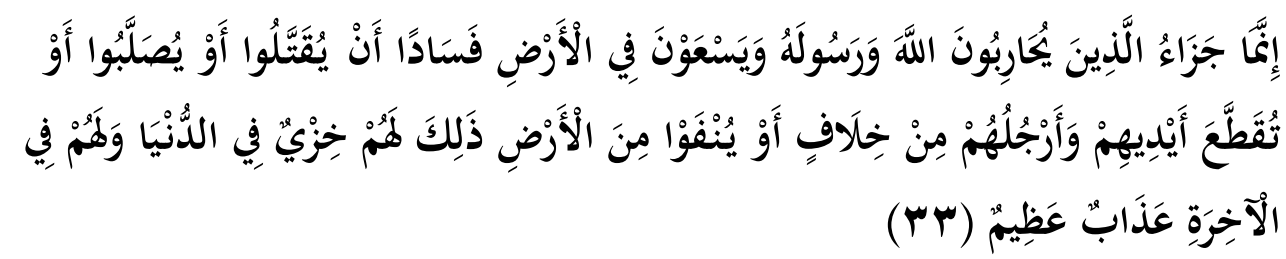

Hukuman bagi orang-orang yang memerangi Allah dan Rasul-Nya dan membuat kerusakan di bumi, hanyalah dibunuh atau disalib, atau dipotong tangan dan kaki mereka secara silang, atau diasingkan dari tempat kediamannya. Yang demikian itu kehinaan bagi mereka di dunia, dan di akhirat mereka mendapat azab yang besar.

Elemen ini mengandung hal utama dalam pendidikan lingkungan hidup tentang larangan untuk berbuat kerusakan di muka bumi. Lingkungan diciptakan oleh Allah tidak untu dirusak. Kerusakan berbagai lingkungan di bumi, adalah ulah manusia yang tidak bertanggungjawab. Islam mengajarkan umatnya untuk menjadi individu yang selaras dengan lingkungan. Memanfaatkan lingkungan untuk kemaslahatan manusia, tidak dengan merusak ataupun perbuatan tidak bertanggungjawab lainnya.

Secara umum siswa mengetahui tentang Islam yang sangat keras dalam melarang manusia untuk berbuat kerusakan di muka bumi. Siswa mengetahui, setidaknya pernah mendapat pengetahuan tentang larangan membuat kerusakan di bumi yang diperoleh dalam guru- 
guru dan ustadz dalam pendidikan di sekolah formal ataupun dalam pendidikan madrasah diniyah. Ayat-ayat dalam al-Quran yang membahas tentang larangan membuat kerusakan di bumi, juga diketahui oleh sebagian besar siswa, meskipun di antara mereka tidak hafal tentang ayat tersebut.

2) Islam menganjurkan kepada manusia untuk mempunyai akhlak yang baik terhadap alam.

Allah memerintahkan manusia untuk berperilaku baik, terhadap makhluk Allah lainnya, seperti: hewan dan tumbuhan. Menyakiti hewan dan tumbuhan merupakan sesuatu yang dilarang dalam Islam, terlebih lagi dengan merusaknya. Banyak sekali firman Allah atau pun hadits Nabi yang memerintahkan manusia untuk mempunyai akhlak yang baik terhadap alam.

Perintah tentang berakhlak baik terhadap alam terdapat banyak dalam al-Qur'an ataupun dalam kisah-kisah Nabi dan Rasul. Sebagian besar siswa mengetahui hal ini. Bahkan sebagian besar dari mereka tahu secara mendetail bagaimana Nabi Sulaiman bersahabat dengan berbagai jenis binatang. Nabi dalam beberapa hadits dijelaskan, bagaimana akhlak beliau terhadap tumbuhan dan hewan. Perintah untuk menyayangi hewan, tidak merusak tanaman, dan sebagainya, harus senantiasa diketahui dan ditanamkan kepada seluruh siswa.

Oleh karena itu, akhlak terhadap alam dalam Islam tidak hanya akhlak dalam pengertian secara etika, tetapi mencakup seluruh aspek seperti keseluruhan sikap, perbuatan, dan tindakan baik terhadap alam. Manusia yang beretika dengan baik ketika ia dapat menjalin hubungan baik dengan Penciptanya (hablum min Allah), dan juga dapat bergaul dengan manusia dengan baik (hablum min al-Nas), termasuk dengan memperlakukan tumbuhan dan hewan-hewan (bagian dari alam) dengan baik. Konservasi dan pemanfaatan alam berfungsi untuk warisan generasi penerus di masa yang akan datang. Salah satu konsep Islam dalam masalah pemanfaatan alam adalah had al-kifayah (standar kebutuhan yang layak). Hal ini berarti keperluan manusia akan sumber daya alam hendaknya secukupnya saja, karena 
pemakaian yang berlebihan dapat merusak kelestarian alam dan keseimbangan ekosistemnya. ${ }^{9}$

3) Allah menjadikan manusia sebagai khalifah di muka bumi, tetapi dalam memanfaatkan alam harus menjaga keseimbangan dan pelestarian lingkungan.

Konsep khalifah dalam hubungannya antara manusia dan alam tidak banyak diketahui oleh siswa. Sebagian siswa, tahu bahwa manusia menjadi pemimpin atau khalifah di muka bumi, tetapi menjadi khalifah di muka bumi dalam konteks memanfaatkan isi alam mereka kurang mengetahuinya. Apalagi kewajiban manusia sebagai khalifah dalam interaksi dengan lingkungannya adalah boleh memanfaatkan alam untuk kebutuhan dan kepentingan manusia, tetapi harus menjaga keseimbangan dan kelestarian lingkungan. Tidak merusak dan mengeksploitasi alam secara tidak bertanggungjawab. Hal inilah yang harus ditanamkan kepada peserta didik, dalam konteks pendidikan lingkungan hidup itu sendiri.

Menurut Haleem ${ }^{10}$, manusia mempunyai peran sebagai wakil Tuhan secara ekologis (ecological khalifah) karena Tuhan menciptakan alam semesta dengan teratur dan sinergis, pengaturan-Nya adalah satu sistem kerja yang saling mendukung dan senantiasa serasi dan tepat (QS. Ar-Rahman ayat 5-7). Alam merupakan amanah yang harus dijaga oleh manusia sebagai khalifah di muka bumi ini. Oleh karena alam adalah amanah (hanya titipan sementara saja), maka ia tidak boleh dirusak dan harus dikembalikan kepada pemilikinya, yaitu Tuhan Yang Maha Kuasa. Sedangkan tujuan penciptaan alam menurut Islam yaitu alam tidak diciptakan begitu saja tanpa alasan (sia-sia) (QS. Al-Ahqaf ayat 3). Alam sebagai pengatur simbiosis mutualisme dapat diartikan sebagai penciptaan alam oleh Tuhan. Di samping sebagai

${ }^{9}$ Muhammad, Agus. (2007). Membangun Ketahanan Masyarakat Menghadapi Bencana: Perspektif Islam tentang Pengurangan Resiko Bencana. Jakarta: CBDRM-NU. HIm 95.

${ }^{10}$ Haleem, Harfiyah. (2006). "The Eclogical Khalifah: Islam and Environment" dalam The Muslim World Book Review. Vol 27. Issue I. Auntum 2006. Hlm 6-19. 
nikmat untuk seluruh umat manusia, alam juga dapat menjadi ujian bagi manusia jika sumber daya alam yang melimpah ini jatuh ke tangan manusia yang tamak dan rakus, yang mengeksploitasi alam tanpa memperhatikan kelestariannya.

Manusia mempunyai posisi yang sangat tinggi, baik dalam hubungannya dengan alam maupun dengan Tuhan, Sang Pencipta Alam. Oleh karena itu, di kalangan para sufi, manusia merupakan wakil Tuhan (khalifah) karena hanya manusia yang mampu memantulkan semua sifat-sifat Tuhan (teomorfis). Kertanegara11 menyatakan potensi teomorfisnya ini, manusia mempunyai mempunyai kewajiban untuk selalu menjaga keselarasan, keharmonisan, dan kesinambungan dengan alam.

4) Allah memandang bahwa orang-orang yang merusak lingkungan merupakan orang-orang yang berbuat melampaui batas

Orang-orang yang merusak lingkungan merupakan orang yang munafik dan sangat tidak disukai Allah Ayat-ayat al-Qur'an dan hadits yang berbicara tentang merusak lingkungan adalah perbuatan orang-orang yang melampaui batas. Merusak lingkungan dalam perspektif Islam, adalah kejahatan yang luar biasa karena akan menimbulkan efek ke berbagai bidang, perbuatan yang keterlaluan atau melampaui batas. Padahal ditinjau dalam berbagai hal, merusak lingkungan itu sangat berbahaya karena berhubungan dengan maslahat hidup orang banyak, dan kerusakan lingkungan yang terjadi juga dalam waktu yang relatif lama.

Di dalam surat Ar Ruum ayat 41 Allah SWT memperingatkan bahwa terjadinya kerusakan di darat dan di laut akibat ulah manusia, yang artinya:

\footnotetext{
${ }^{11}$ Kertanegara, Mulyadi. (2006). Gerbang Kearifan: Sebuah Pengantar Filsafat Islam. Jakarta: Lentera Hati. Hlm 112 - 113. 


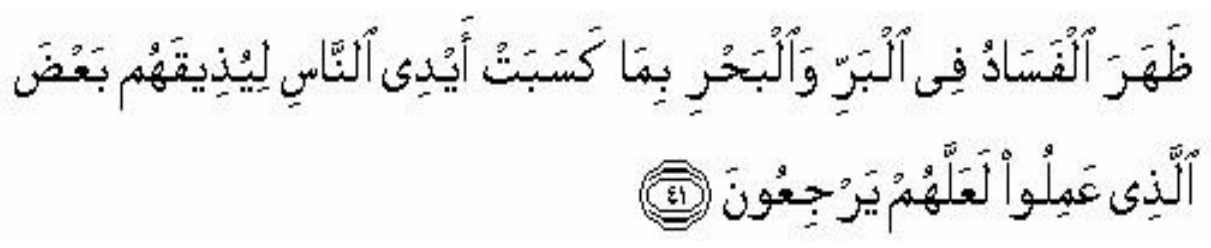

Telah nampak kerusakan di darat dan di laut disebabkan karena perbuatan tangan manusia, supaya Allah merasakan kepada mereka sebahagian dari (akibat) perbuatan mereka, agar mereka kembali (ke jalan yang benar) (QS. Ar-Rum: 41)

Serta surat Al Qashash ayat 77 menjelaskan sebagai berikut.

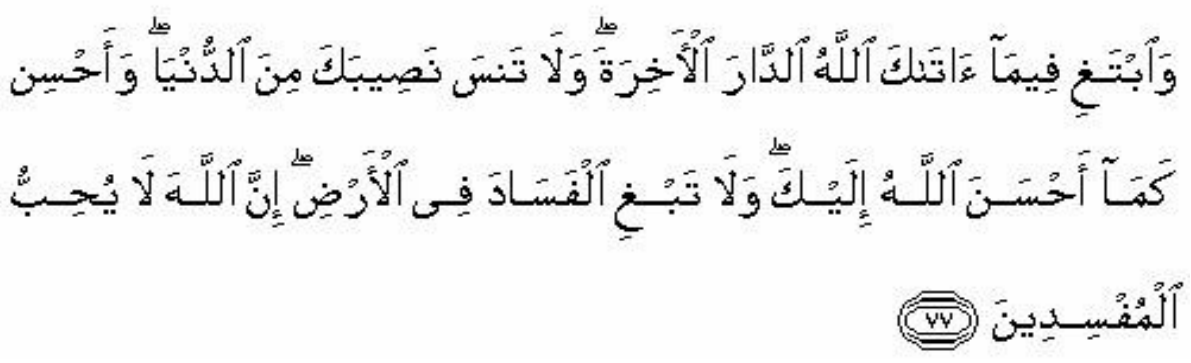

Dan carilah pada apa yang telah dianugerahkan Allah kepadamu (kebahagiaan) negeri akhirat, dan janganlah kamu melupakan bahagianmu dari (kenikmatan) duniawi dan berbuat baiklah (kepada orang lain) sebagaimana Allah telah berbuat baik, kepadamu, dan janganlah kamu berbuat kerusakan di (muka) bumi. Sesungguhnya Allah tidak menyukai orang-orang yang berbuat kerusakan. (QS. AlQashash: 77).

Firman Allah SWT di dalam surat Ar Ruum ayat 41 dan surat Al Qashash ayat 77 menekankan agar manusia berlaku ramah terhadap lingkungan dan tidak berbuat kerusakan di muka bumi ini. Dari keterangan di atas, jelaslah aturan-aturan agama Islam yang menganjurkan untuk menjaga kebersihan dan lingkungan. Semua larangan tersebut dimaksudkan untuk mencegah agar tidak mencelakakan orang lain, sehingga terhindar dari musibah yang 
menimpahnya. Islam memberikan panduan yang cukup jelas bahwa sumber daya alam merupakan daya dukung bagi kehidupan manusia, sebab fakta spritual menunjukkan bahwa terjadinya bencana alam seperti banjir, longsor, serta bencana alam lainnya lebih banyak didominasi oleh aktifitas manusia. Allah SWT Telah memberikan fasilitas daya dukung lingkungan bagi kehidupan manusia. Oleh karena itu, secara yuridis fiqhiyah berpeluang dinyatakan bahwa dalam perspektif hukum Islam status hukum pelestarian lingkungan hukumnya adalah wajib. ${ }^{12}$

Secara umum interaksi manusia dan lingkungan dalam pandangan Islam adalah agar manusia menjadi pelaku aktif lingkungan serta melestarikannya. Dalam Al-Qur'an Surat Ar-Rum ayat 9 memerintahkan agar manusia menjadi pelaku aktif dalam mengolah lingkungan serta melestarikannya.

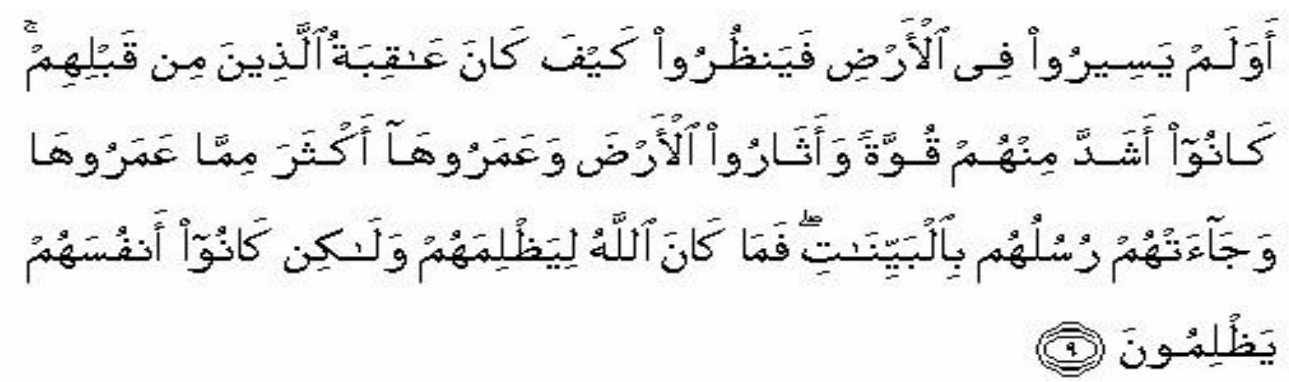

"Dan apakah mereka tidak mengadakan perjalanan di muka bumi dan memperhatikan bagaimana akibat (yang diderita) oleh orang-orang sebelum mereka? orang-orang itu adalah lebih kuat dari mereka (sendiri) dan telah mengolah bumi (tanah) serta memakmurkannya lebih banyak dari apa yang telah mereka makmurkan. Dan telah datang kepada mereka rasul-rasul mereka dengan membawa bukti-bukti yang nyata. Maka Allah sekali-kali tidak berlaku zalim kepada mereka, akan tetapi merekalah yang berlaku dzalim kepada diri sendiri.

\footnotetext{
${ }^{12}$ Abdillah, M. (2005). Fikih Lingkungan. Yogyakarta: UPP AMP YKPN. Hlm 11 -
} 12. 
Pesan yang disampaikan dalam surat Ar Ruum ayat 9 di atas menggambarkan agar manusia tidak mengeksploitasi sumber daya alam secara berlebihan yang dikhawatirkan terjadinya kerusakan serta kepunahan sumber daya alam, sehingga tidak dapat diwariskan untuk generasi mendatang. Untuk itu Islam mewajibkan agar manusia menjadi pelaku aktif dalam mengolah lingkungan serta melestarikannya. Seorang Muslim memandang alam sebagai milik Allah SWT yang wajib disyukuri dengan cara menggunakan dan mengelola alam dengan sebaik-baiknya sehingga dapat memberikan manfaat bagi manusia itu sendiri. Pemanfaatan alam yang diajarkan adalah pemanfaatan yang didasari oleh sikap tanggungjawab. Alam yang memberikan keuntungan tidak hanya diambil kandungannya saja tetapi juga supaya alam tetap utuh dan lestari dengan cara memberikan kesempatan kepada alam untuk melakukan rehabilitasi atau membantu mempercepat pemulihannya kembali.

\section{Strategi Implementasi Pandangan Islam Tentang Pendidikan Lingkungan Hidup dalam Pembelajaran}

Penguatan karakter mencintai lingkungan perlu dilakukan dengan berbagai strategi dan pendekatan untuk mencapai hasil yang optimal. Kompetensi yang diharapkan dari pendidikan lingkungan hidup adalah terbentuknya pengetahuan, sikap, dan keterampilan siswa yang selaras dengan keseimbangan dan keserasian lingkungan hidup.

Secara khusus, implementasi pandangan Islam tentang pendidikan lingkungan hidup dalam pembelajaran perlu dilakukan dengan strategi sebagai berikut.

1. Memasukkan secara tegas dalam pembelajaran Pendidikan Agama Islam

Dalam mata pelajaran Pendidikan Agama Islam, mulai dari jenjang SD sampai dengan SMA perlu memasukkan secara khusus dan tegas tentang Islam dan lingkungan hidup yang disesuaikan dengan kompetensi dan bahasan dalam mata pelajaran PAI sesuai tingkatan kelas dan sekolah. Kemampuan guru PAI dalam memasukkan elemen lingkungan hidup dalam perspektif Islam mutlak diperlukan, terutama 
materi yang berkaitan dengan muatan akhlak, yaitu akhlak terhadap lingkungan.

2. Menginsertkan dalam mata pelajaran atau tema

Secara khusus, guru harus menginsertkan materi lingkungan hidup dalam perspektif Islam dalam berbagai tema dan mata pelajaran dalam pembelajaran di sekolah. Integrasi dengan tema ini dapat digunakan ketika menganalisis permasalahan lingkungan dalam berbagai kajian integratif dalam berbagai disiplin ilmu. Tentunya, komitmen dan kemampuan guru menjadi menjadi mutlak dalam mengintegrasikan lingkungan hidup dalam perspektif Islam. Ada banyak elemen pembelajaran dalam mata pelajaran dan tema yang bisa dimasukkan elemen lingkungan hidup dalam perspektif Islam.

3. Mengkaji ayat-ayat al-Qurán atau hadits Nabi tentang lingkungan hidup Dalam tingkatan SMP dan SMA mempelajari tafsir dengan membedah dan mengkritisi ayat-ayat al-Qurán atau hadits Nabi tentang lingkungan hidup dapat memperkuat pemahamana siswa dengan lingkungan hidup dalam perspektif Islam. Banyak ayat atau hadits yang berbicara tentang lingkungan, dengan membedah dan mengkritisi diharapkan pemahaman dan pengetahuan peserta didik dapat menjadi lebih baik dan komprehensif dalam memandang lingkungan yang bermuara pada peningkatan sikap dan keterampilan siswa tentang lingkungan hidup.

\section{Penutup}

Islam dapat menjadi dasar dan menopang utama bagaimana membangun karakter peserta didik terhadap lingkungan melalui pendidikan lingkungan yang diintegrasikan dengan nilai-nilai Islam. Islam melarang secara tegas dan keras kepada manusia untuk berbuat kerusakan di muka bumi sebagai sumber dari bencana alam sekaligus menganjurkan kepada manusia untuk mempunyai akhlak yang baik terhadap alam. Allah menjadikan manusia sebagai khalifah di muka bumi, tetapi dalam memanfaatkan alam harus menjaga keseimbangan dan pelestarian lingkungan, orang-orang yang merusak lingkungan merupakan orang yang munafik dan sangat tidak disukai Allah. Allah memandang bahwa 
orang-orang yang merusak lingkungan merupakan orang-orang yang berbuat melampaui batas. Elemen nilai Islam terhadap lingkungan dapat dijadikan materi dan landasan utama dalam pendidikan lingkungan hidup di sekolah.

Secara khusus, implementasi pandangan Islam tentang pendidikan lingkungan hidup dalam pembelajaran perlu dilakukan dengan strategi memasukkan secara tegas dalam pembelajaran Pendidikan Agama Islam, menginsertkan dalam mata pelajaran atau tema, dan mengkaji ayat-ayat alQurán atau hadits Nabi tentang lingkungan hidup.

\section{DAFTAR PUSTAKA}

Abdillah, M. 2005. Fikih Lingkungan. Yogyakarta: UPP AMP YKPN.

Basri, Hasan Mohammad, dkk. 2012. "Paradigma Eko-Filosofi: Melacak Titik Temu Sains, Agama (Islam) dan Budaya (Jawa) dalam Memaknai, dan Mengantisipasi Bencana" dalam Agama, Budaya, dan Bencana, Editor: Agus Indiyanto \& Arqom Kuswanjono. Bandung: Mizan.

Chang, William. 2001. Moral Lingkungan Hidup Yogyakarta: Penerbit Kanisius

Gyallay, Peter. Environment: PAP-ETAP Reference Guide Book, Chapter 13. 2004 (http//www.un.org.kh/fae/pdfs/ section4/chapterxxx3/33 .pdf).

Haleem, Harfiyah. 2006. "The Eclogical Khalifah: Islam and Environment" dalam The Muslim World Book Review. Vol 27. Issue I. Auntum 2006

Hines, et.al. (2004). Global Issues and Environment Education. (http//www. eriese.org/erie/digest/digest-05/ html) (12 Oktober 2019). 
Ichwan, Moch. Nur. 2012. "Eko-Teologi Bencana, Aktivisme Sosial, dan Politik Kemasalahatan" dalam Agama, Budaya, dan Bencana, Editor: Agus Indiyanto \& Arqom Kuswanjono. Bandung: Mizan.

Kertanegara, Mulyadi, 2006. Gerbang Kearifan: Sebuah Pengantar Filsafat Islam. Jakarta: Lentera Hati.

Muhammad, Agus, 2007. Membangun Ketahanan Masyarakat Menghadapi Bencana: Perspektif Islam tentang Pengurangan Resiko Bencana. Jakarta: CBDRM-NU.

Muhaimin. 2015. Membangun Kecerdasan Ekologis: Model Pendidikan Untuk Peningkatan Kompetensi Ekologis. Bandung: Alfabeta.

Palmer, J. A \& Phlip, N (1994). The Handbook of Environmental Education. London: Routledge. 